\title{
Sperm DNA integrity of the rat treated with different concentration of Aloe vera gel extract
}

\author{
Ni Made Sawitri ${ }^{1}$, Nisa Maharani ${ }^{1}$, Rahmi Maulidya Putranty ${ }^{1}$, Rico Sutandy ${ }^{1}$, \\ I. Wayan Nico Fajar Gunawan'², I. Ketut Puja ${ }^{1}$
}

${ }^{1}$ Veterinary Genetics and Reproduction Technology Laboratory, Faculty of Veterinary Medicine, Udayana University, Kabupaten Badung, Bali 80361, Indonesia, ${ }^{2}$ Veterinary Surgery and Radiology Laboratory, Faculty of Veterinary Medicine, Udayana University, Kabupaten Badung, Bali 80361, Indonesia

\begin{abstract}
Objective: The aim of this study was to evaluate the effect of Aloe vera gel on sperm DNA integrity in rats. Materials and Methods: This research used completely random design using 24 male rats (Rattus novergicus) weighing 210-220 g. The rats were divided into four groups with six rats in each group. Group 0 (T0) was treated with distilled water as placebo. Group 1 (T1) was given with $200 \mathrm{mg} / \mathrm{kg}$ body weight $A$. vera gel, Group 2 (T2) was given with $300 \mathrm{mg} / \mathrm{kg}$ body weight $A$. vera gel, while Group 3 (T3) was treated with $400 \mathrm{mg} / \mathrm{kg}$ body weight $A$. vera gel. A. vera gel was given every day for 21 days orally to evaluate the effect on sperm DNA integrity. Results: The rat administration of $A$. vera gel with a dose of $400 \mathrm{mg} / \mathrm{kg}$ body weight significantly increases on the sperm DNA damage. Conclusions: The finding of this research indicates that $A$. vera gel affected the DNA integrity of spermatozoa, and its use is to be restricted in male animals, especially those used for breeding.
\end{abstract}

Key words: Aloe vera, contraception, DNA integrity, orally

\section{INTRODUCTION}

$\mathrm{D}$ uring the past 10 years, the development and use of medicinal plants have become more popular in the world. One of the well-known and popular plants is Aloe vera and has been used for its health for thousands of years of many cultures ${ }^{[1]} A$. vera leaves contain numerous compound such as vitamins and folic acid, ${ }^{[2]}$ calcium, sodium, sugars, aminoacids and other active constituents ${ }^{[3]}$ and has been used for medicinal purpose.$^{[4]}$ A. vera is a wonder plant with numerous health benefits. There is some study evidence that $A$. vera gel was used to treatment of infection, potent antimicrobial drugs, ${ }^{[5]}$ diabetic, and rheumatic pain. ${ }^{[6]}$

Recently, various studies reported that the $A$. vera plant has been associated with many side effects. It may cause redness, burning, and dermatitis after topical application. ${ }^{[2]} A$. vera can affect the male reproductive tract of mice, ${ }^{[7]}$ can affect spermatozoa production, and can decrease the fertility of males. ${ }^{[8]}$ In males, A. vera was reported to contribute to the increased biodistribution of sodium ions in testes ${ }^{[9]}$ followed by fluid movement into testes. ${ }^{[10]}$ Changes in osmolarity and tonicity as a result of the increased flow of sodium ions into the testes cause increased spermatozoa abnormalities. This is due to the inability of spermatozoa to tolerate changes in cell osmolarity in the testes. ${ }^{[1]}$

A. vera administration orally continues until 21 days, resulting in weight loss and decreased fertility in white rats. ${ }^{[12]}$ Decreased spermatozoa function will lead to a decline in fertilization and premature death of the embryo. One key to the success of fertilization and embryo development is the sperm DNA integrity. ${ }^{[13]}$

There are various methods used to assess the damage of spermatozoa DNA. Staining of spermatozoa with acridine

\section{Address for correspondence: \\ I. Ketut Puja, Veterinary Genetics and Reproduction \\ Technology Laboratory, Faculty of Veterinary Medicine, Udayana University, Kabupaten Badung, Bali 80361, Indonesia.}

Received: $30-03-2018$

Revised: 06-10-2018

Accepted: 09-11-2018 
orange (AO) has been used for the assessment of DNA damage. ${ }^{[14]}$ The current research aspects of $A$. vera gel extracts on DNA damage have not been reported. Therefore, this study was designed to assess the effect of $A$. vera gel on the rat sperm DNA integrity.

\section{MATERIALS AND METHODS}

\section{Experimental Animal}

A total of 24 fertile male Wistar rats, weighed $200-300 \mathrm{~g}$ at the age of 3-4 months, were selected. The rats were placed in cages made from plastic boxes of about $60 \mathrm{~cm}$ in length and $40 \mathrm{~cm}$ in width with a roof made by wire. Cat litter was used as bedding and was changed every once a week. The rats were give water feed ad libitum. This study used four groups of treatment (T0-T3) of 6 rats each. The first group (T0) is control given distilled water, while the Groups T1, $\mathrm{T} 2$, and T3 were given 200,300 , and $400 \mathrm{mg} / \mathrm{kg}$ of the gel, respectively. These rats were threaten $A$. vera gel orally daily every morning using oral cannula for 21 consecutive days.

\section{A. Vera Gel Extract Preparation}

The A. vera sample was washed and rinsed of stream water and air dried. The gel was obtained by incision in the middle of leaves and then the inner part was scrapped. The gel was carefully collected into a beaker glass. Amount of 2.0, 3.0 , and $4.0 \mathrm{~g}$ of the gel was added with $100 \mathrm{ml}$ of distilled water to make $2 \%, 3 \%$, and $4 \%$ solutions of the extract, respectively.

\section{Sample Collection}

The rats were given of gel for 21 days and the samples were collected on the $23^{\text {th }}$ day. Rats from each group were anesthetized using combination of xylazine and ketamine. The testes were collected by castration methods. Sperm cells were obtained from the cauda epididymis. The collected sample was prepared and stained with AO for sperm DNA integrity test.

\section{Assessment of DNA Integrity}

The air-dried smears were stained with AO. Thereafter, the slide was gently rinsed in distilled water. 100 spermatozoa were evaluated under an fluorescent microscope. ${ }^{[12]}$ Sperm with a spectrum of yellow-orange to red fluorescence was considered with damaged DNA, whereas spermatozoa with green fluorescence were considered with normal DNA. The AO test was performed as described in detail by Tejada et al. ${ }^{[15]}$ with slight modifications.

\section{Statistical Analysis}

Data were analyzed using one-way analysis of variance (ANOVA). Differences among groups were evaluated using Duncan's multiple range test. ${ }^{[16]}$

\section{RESULTS}

The present study rats treated with $400 \mathrm{~g} / \mathrm{kg}$ bw of $A$. vera gel extract showed significantly higher of partially fragmented DNA compared with other treatment. AO test found an increase in the percentage of $\mathrm{AO}$ green to yellow cells in treated $400 \mathrm{~g} / \mathrm{kg}$ bw group compared with other group treatment.

There was a significant effect in sperm DNA integrity of group that received treatment of $400 \mathrm{~g} / \mathrm{kg}$ bw of $A$. vera gel extract compared to control, $200 \mathrm{~g} / \mathrm{kg}$ bw, and $300 \mathrm{~g} / \mathrm{kg}$ bw $(P<0.05)$. The mean percentage of DNA integrity of spermatozoa observed throughout the study was $4.16 \pm 0.30 \%, 4.33 \pm 0.33 \%, 5.83 \pm 0.47 \%$, and $6.33 \pm 0.55 \%$ for the control, $\mathrm{T} 1, \mathrm{~T} 2$, and $\mathrm{T} 3$, respectively [Table 1].

\section{DISCUSSION}

There are a few studies related to the effects of $A$. vera gel extract on the reproductive system. A. vera gel extract has been observed effect on quality of spermatozoa. ${ }^{[8]}$ In these studies, besides, the effect of $A$. vera gel on sperm concentration and motility also observed to determine the percentage of viability.

In the present study, the DNA damage evaluation of spermatozoa showed that treatment groups had marked defects in DNA integrity. The present research showed a significant increase in the DNA damage in treated $400 \mathrm{~g} / \mathrm{kg} \mathrm{bw}$ of $A$. vera gel extract-treated group compared to other group. $A$. vera gel extract treatments to male rats caused partially denatured of DNA. This result is suggestive of the damage of spermatozoa as reported by Oyeyemi et al ${ }^{[8]}$ Futhermore, there was a previous report of spermatozoa damage findings by Oyewepo et al. ${ }^{[17]}$ who suggested that $A$. vera gel extract contains compound which has toxic properties that can cause

\begin{tabular}{lccc}
\multicolumn{3}{c}{ Table 1: Effect of Aloe vera gel on sperm DNA } \\
integrity \\
\hline \multirow{4}{*}{ Treatments } & \multicolumn{3}{c}{ DNA integrity } \\
\cline { 2 - 4 } & Minimum & Maximum & Mean+SE \\
\hline $0 \mathrm{~g} / \mathrm{kg}$ (control) & 3 & 5 & $4.16 \pm 0.30$ \\
$200 \mathrm{~g} / \mathrm{kg} \mathrm{(T1)}$ & 3 & 5 & $4.33 \pm 0.33$ \\
$300 \mathrm{~g} / \mathrm{kg}$ (T2) & 4 & 7 & $5.83 \pm 0.47$ \\
$400 \mathrm{~g} / \mathrm{kg}$ (T3) & 4 & 8 & $6.33 \pm 0.55$ \\
\hline
\end{tabular}


damage to spermatozoa. The studies also revealed an increase of DNA damage in contrast with the findings of Zohreh et al. ${ }^{[18]}$ who reported that $A$. vera is rich in antioxidant properties could prevent spermatozoa from damaged.

Staining of cells with AO has been widely accepted as a predictor of DNA damage in many cell types ${ }^{\left[{ }^{[19]}\right.}$ The present study was the first study performed to determine the DNA integrity using AO. The DNA damage in this research were due to the biodistribution increase of sodium ion into testes. The results of the present study also suggest that the mechanism of $A$. vera gel-induced damage to the male reproductive tract is independent of oxidative stress.

\section{CONCLUSIONS}

Administration of $4 \%$ of $A$. vera extract can induce DNA damage of spermatozoa of male Wistar rats.

\section{ACKNOWLEDGMENT}

The authors would like to thank the Ministry of Research, Technology and Higher Education of the Republic of Indonesia for financial support by PKM grant research 2016. We also thanks the Staff of Veterinary Genetics and Reproduction Technology Laboratory, Faculty of Veterinary Medicine, Udayana University, for technical assistance to prepare the sample.

\section{CONFLICTS OF INTEREST}

The authors declare that they have no conflicts of interest.

\section{REFERENCES}

1. Grundmann O. An overview of its clinical uses and proposed mechanisms of action. Nat 1 Med J 2012;4:1-13.

2. Rajeswari R, Umadevi M, Rahale CS, Pushpa R, Selvavenkadesh S, Sampath Kumar KP, et al. Aloe vera: The miracle plant its medicinal and traditional uses in India. J Pharmacogn Phytochem 2012;1:118-24.

3. Sahu PK, Giri DD, Singh R, Pandey P, Gupta S, Shrivastava AK, et al. Therapeutic and medicinal uses of Aloe vera: A review. Pharmacol Pharm 2013;4:599-610.

4. Hamman JH. Composition and applications of Aloe vera leaf gel. Molecules 2008;13:1599-616.

5. Malar TR, Johnson M, Beaulah SN, Laju RS, Anupriya G, Ethal TR. Anti-Bacterial and antifungal activity of Aloe vera gel extract. Int J Biomed Adv Res 2012;3:184-7.

6. Nandal U, Bhardwaj RL. Aloe vera for human nutrition, health and cosmetic use: A review. Int Res J Plant Sci 2012;3:38-46.

7. Ahbab MA, Korkmaz A, Barlas N, Gürbüz I, Çok I. Biochemical and histological alterations in reproductive tract tissues of male swiss albino mice exposed commercially prepared Aloe vera gel product. Hacettepe J Biol Chem 2014;42:351-60.

8. Olugbenga OM, Olukole SG, Adeoye AT, Adejoke AD. Semen characteristics and sperm morphological studies of the west african dwarf buck treated with Aloe vera gel extract. Iran J Reprod Med 2011;9:83-8.

9. Holanda CM, Costa MB, Silva NC, Junior MF, Barbosa VS, Silva RP, et al. Effect of an extract of Aloe vera on the biodistribution of sodium pertehnetate (Na99m Tc04) in rats. Acta Cir Bras 2009;24:5.

10. Byers S, Graham R. Distribution of sodium potassium ATPase in the rat testis and epididimys. Am J Anaomy 1989;188:31-43.

11. Foote RH. Fertility of bull semen at high extensive rates in trisbufferes extenders. J Dairy Sci 1970;53:1475-7.

12. Oyeyemi MO, Fayomi AP. Gonadosomatic index and spermatozoa morphological characteristics of male wistar rats treated with graded concentration of Aloe vera gel. Int J Anim Vet Adv 2011;3:47-53.

13. Lopes S, Sun JG, Jurisicova A, Meriano J, Casper RF. Sperm deoxyribonucleic acid fragmentation is increased in poor-quality semen samples and correlates with failed fertilization in intracytoplasmic sperm injection. Fertil Steril 1998;69:528-32.

14. Thuwanut $\mathrm{P}$, Chatdarong $\mathrm{K}$, Techakumphu M, Axnér E. The effect of antioxidants on motility, viability, acrosome integrity and DNA integrity of frozen-thawed epididymal cat spermatozoa. Theriogenology 2008;70:233-40.

15. Tejada RI, Mitchell JC, Norman A, Marik JJ, Friedman S. A test for the practical evaluation of male fertility by acridine orange (AO) fluorescence. Fertil Steril 1984;42:87-91.

16. Heath D. An Introduction to Experimental Design and Statistics for Biology. London: UCL Press; 2001.

17. Oyewepo AO, Oremasu AA, Akang EN, Noronha CC, Okanlawon AO. Effects of Aloe vera (Aloe barbadensis) aqueous leaf extract on testicular weight. Sperm count and motility of adult male sprague-dawley rats. J Am Sci 2011;7:31-4.

18. Zohreh N, Shahla R, Reza M. The effect of Aloe vera extract on the spermquality in male diabetic rats. Bull Env Pharmacol Life Sci 2014;3:223-8.

19. Chohan KR, Griffin JT, Carrell DT. Evaluation of chromatin integrity in human sperm using acridine orange staining with different fixatives and after cryopreservation. Andrologia 2004;36:321-6.

Source of Support: Nil. Conflict of Interest: None declared. 